\title{
The GABAergic Effect of Low Doses of Lorazepam on Social Behavior
}

\author{
María Pérez Conchillo, Sonia Martínez-Sanchis, Alicia Salvador, and \\ Vicente M. Simón*
}

Area de Psicobiología, Facultad de Psicología, Universitat de València, Valencia, Spain

: : : : : : : : : : : : : : : : : : : : : : : : : : : : : : :

The aim of this work was to test the antiaggressive effects of lorazepam and to determine whether these effects were mediated by benzodiazepine receptors. In a first experiment, male mice were injected with lorazepam in a range of low doses $(0.05,0.1,0.2$, and $0.6 \mathrm{mg} / \mathrm{kg})$ or saline solution. In a second experiment, $1 \mathrm{mg} / \mathrm{kg}$ of Ro 15-1788, a benzodiazepine receptor antagonist, and a saline solution were injected before the behavioral test. Results showed that $0.6 \mathrm{mg} / \mathrm{kg}$ of lorazepam was the only dose that decreased the total duration of threat $(P<.01)$ and social investigation $(P<.05)$ and that $1 \mathrm{mg} / \mathrm{kg}$ of Ro $15-1788$ had no effects. In the third experiment, animals received two injections: $0.6 \mathrm{mg} / \mathrm{kg}$ of lorazepam plus $1 \mathrm{mg} / \mathrm{kg}$ of Ro $15-1788,0.6 \mathrm{mg} / \mathrm{kg}$ of lorazepam plus saline solution, or saline solution plus saline solution. Those treated with lorazepam and saline solution spent less time digging $(P<.001)$, threatening $(P<.001)$, and attacking $(P<.05)$ and more time avoiding the opponent $(P<.01)$ or being immobile $(P<.001)$ than the controls. Ro 15-1788 was successful in completely antagonizing the behavior modulated by lorazepam. Aggr. Behav. 28:248256, 2002. 이 2002 Wiley-Liss, Inc.

: : : : : : : : : : : : : : : : : : : : : : : : : : : : : : : : :

Key words: benzodiazepines; lorazepam; aggression; social behavior; male mice; Ro 15-1788

\section{INTRODUCTION}

In the past few decades, the effects of benzodiazepines on aggression have been investigated in numerous pharmacological studies [Christmas and Maxwell, 1970; Cilia and Piper, 1997; Da Vanzo et al., 1966; Krsiak, 1979; Krsiak et al., 1981; Mos and Olivier, 1989; Pabis and Stanislav, 1996; Parmigiani et al., 1998; Poshivalov et al., 1987; Vale and Montgomery, 1997], but, on the whole, it could be said that there is no complete agreement as to their action on this behavior. Classically, decreases in aggression have been reported as a consequence of treatment with these drugs, although several researchers have reported increases, naming them "benzodiazepines' paradoxical effect" [Cutler et al., 1997; Feldman, 1986; Weerts and Miczek, 1996; Weisman et al., 1998].

With respect to the relationship between benzodiazepines and isolation-induced aggression, the most investigated drugs have been chlordiazepoxide and diazepam. The results, however, have proved to be contradictory because doses between 5 and $50 \mathrm{mg} / \mathrm{kg}$ of chlordiazepoxide in

*Correspondence to: Dr. Vicente M. Simón, Area de Psicobiología, Facultad de Psicología, Apartado 22109, 46071 Valencia, Spain. E-mail: Alicia.Salvador@uv.es

Received 29 August 2000; amended version accepted 21 December 2000

Published online in Wiley InterScience (www. interscience.wiley.com). DOI: 10.1002/ab.90025 
most cases have reduced aggression [Da Vanzo et al., 1966; Ferrari et al., 1997; Krsiak, 1975; Krsiak, 1979; Miczek and O'Donnell, 1980; Poole, 1973; Scriabine and Blake, 1962; Sofia, 1969; Sulcova and Krsiak, 1989; Vale and Montgomery, 1997; Valzelli and Bernasconi, 1976; Valzelli et al., 1967], although on some occasions no effects [Krsiak, 1979; Miczek and O'Donnell, 1980] or even increases with the same dose and type of administration have been observed [Borgesova et al., 1971]. Other benzodiazepine substances, such as alprazolam and oxacepam, have acted to reduce defense behavior and attack and increase social investigation and nonsocial exploration [Delini-Stula and Vassout, 1979; Krsiak and Sulcova, 1990; Sulcova and Krsiak, 1989], although low doses have had no effect on attack [Krsiak and Sulcova, 1990]. Several factors, such as individual differences and/or the use of different substances, have explained the contradictory results.

Lorazepam (commercial name, Orfidal), a benzodiazepine that is frequently being used at the present in clinical practice, is one of the less-studied benzodiazepines in relation to aggressive behavior. Comparisons with other benzodiazepines (alprazolam, diazepam, nitrazepam, and oxacepam) have shown that lorazepam has a higher sedative potency [Krsiak and Sulcova, 1990; Sulcova and Krsiak, 1989]. Independently of this effect, lorazepam, as other benzodiazepines, has proved to be more effective than neuroleptics in the management of aggression and agitation [Buckley, 1999; Dorevitch, et al., 1999; Lenox et al, 1992; Salzman et al., 1991], although the most effective choice is the combination with a neuroleptic [Bieniek et al., 1998]. Using the isolation-induced aggression model, Sulcova and Krsiak [1989] and Krsiak and Sulcova [1990] found that lorazepam diminished the occurrence of defenses and escapes at doses that decreased motor activity, reduced aggressive behavior (attacks) at doses that suppressed rearing, and had no effects on attack at low doses $(0.2$ and $0.6 \mathrm{mg} / \mathrm{kg})$.

The "taming" or antiaggressive effects of benzodiazepines are due to their action as benzodiazepine receptor agonists at the GABA receptor complex. GABAergic and opioidergic neurotransmissions are more closely related to modifications in aggressive, defensive, and submissive behaviors compared with serotoninergic and dopaminergic action [Miczek et al., 1994]. The inhibiting effect of the GABAergic system on aggression has been suggested by several studies using neuropharmacological manipulations. This is the case of Mandel et al. [1981] who, after injection of GABA into the olfactory bulb, found temporary inhibition of the muricide behavior in rats. At the same time, they found lower GABA levels in this area in muricide rats compared with the nonmuricide.

Ro 15-1788 (flumazenil) is a benzodiazepine receptor antagonist that antagonizes the central effects of benzodiazepines [Bonetti et al., 1982; Skolnick et al., 1985] and that also has several behavioral effects at moderate-high doses. Ro 15-1788 blocks the benzodiazepine receptors, increasing motor activity and social investigation at doses between 1.25 and $20 \mathrm{mg} / \mathrm{kg}$ [Rodgers and Waters, 1984; Rodgers et al., 1983] and reverting the low levels of aggression induced by diazepam and beta-carboline [Skolnik et al., 1985]. This substance at doses between 20 and 40 $\mathrm{mg} / \mathrm{kg}$ blocks the analgesic effect of defeat [Rodgers and Randall, 1987, 1988] and at doses higher than $40 \mathrm{mg} / \mathrm{kg}$ induces seizures [Corda et al., 1982]. The proconvulsive action could be related to the hypothesis that considers that flumazenil could act as a partial agonist of benzodiazepine receptors at very high doses [File, 1982; Nutt et al., 1982; Rodgers and Randall, 1988; Rodgers et al., 1983]. Miachon and Cespuglio [1997] found that as a benzodiazepine receptor antagonist, pretreatment with flumazenil (Ro 15-1788) prevented the adrenalectomy-induced muricidal behavior in male wistar rats. The corticotropin-induced muricidal behavior was prevented by flumazenil, although the posttreatment had no effects. The benzodiazepine receptors have been involved in this inhibiting effect. 
The main aims of the present study were to determine the effect on social behavior of lorazepam (a benzodiazepine receptor agonist) and Ro 15-1788 (a benzodiazepine receptor antagonist) and their action on individually housed male mice during an agonistic encounter in a neutral area. In the first experiment, we studied the effects of a single administration in a range of low doses $(0.05,0.1,0.2$, and $0.6 \mathrm{mg} / \mathrm{kg})$ of lorazepam to select the dose that had the greatest effect on agonistic behavior. In Experiment 2, to verify the lack of behavioral effects of Ro 15-1788 at low doses, a single administration of $1 \mathrm{mg} / \mathrm{kg}$ of this drug and a saline solution were injected before the behavioral test. Finally, as in the first experiment, the most efficient dose at reducing aggression turned out to be $0.6 \mathrm{mg} / \mathrm{kg}$; this was the dose selected to be used in Experiment 3, and to confirm its specificity of action at the benzodiazepine receptor, a second injection with Ro 15$1788(1 \mathrm{mg} / \mathrm{kg})$ was given before the behavior was tested.

\section{MATERIALS AND METHODS}

\section{Subjects}

Five hundred sixty-four OF1 male mice from Iffa Credo (France), aged 42 days, were employed in the three experiments. Half of them were individually housed for 6 weeks in plastic cages $(24 \times 13 \times 14 \mathrm{~cm})$ and used as experimental and control subjects. The other animals were housed in groups of 10 in larger cages $(28 \times 28 \times 14 \mathrm{~cm})$ and used as "standard opponents" after being rendered temporally anosmic by intranasal lavage with a $4 \%$ zinc sulphate solution a day before testing. Mice were fed food (Panlab) and water ad libitum and subjected to a 12-hour light-dark cycle (lights on 10:00-22:00 hours local time). Laboratory temperature was kept at 20 $\pm 2{ }^{\circ} \mathrm{C}$. Subjects were weighed once a week.

\section{Procedure}

Drug administration. The lorazepam employed was by courtesy of Septa Farma Laboratory (Barcelona, Spain) and the Ro 15-1788 was by courtesy of Roche Laboratory (commercial name Anexate; Barcelona, Spain).

Experiment 1. Four groups of animals were injected intraperitoneally with $0.05(\mathrm{n}=13), 0.1$ $(\mathrm{n}=12), 0.2(\mathrm{n}=14)$, or $0.6(\mathrm{n}=14) \mathrm{mg} / \mathrm{kg}$ of lorazepam and one group $(\mathrm{n}=13)$ with $5 \mathrm{ml} / \mathrm{kg}$ of physiological saline solution (control group) $30 \mathrm{~min}$ before the behavioral test.

Experiment 2. The experimental group $(\mathrm{n}=14)$ received an intraperitoneal injection of $5 \mathrm{ml} / \mathrm{kg}$ of physiological saline solution $30 \mathrm{~min}$ before the behavioral test and an injection of $1 \mathrm{mg} / \mathrm{kg}$ of Ro $15-1788$ twenty minutes after the first injection. The control group $(\mathrm{n}=$ 14) was injected with $5 \mathrm{ml} / \mathrm{kg}$ of physiological saline solution 30 and $10 \mathrm{~min}$ before the behavioral test.

Experiment 3. Two groups of animals were injected intraperitoneally with $0.6 \mathrm{mg} / \mathrm{kg}$ of lorazepam $30 \mathrm{~min}$ before the behavioral test. Twenty minutes after the first injection, one of them received an intraperitoneal injection with physiological saline $(n=14)$ and the other with $1 \mathrm{mg} / \mathrm{kg}$ of Ro 15-1788 $(\mathrm{n}=13)$. Finally, a third group, the control $(\mathrm{n}=14)$, was injected with $5 \mathrm{ml} / \mathrm{kg}$ of physiological saline solution 30 and $10 \mathrm{~min}$ before the behavioral test.

Social encounter test. Encounters lasting 10 min between an isolated mouse and an anosmic opponent in a neutral area $(60 \times 40 \times 20$ transparent glass cage $)$ illuminated by a white light $(60$ W) were carried out. This was preceded by a minute of adaptation in which the animals were separated by a plastic partition. Encounters (in which each animal participated only once) took place starting in the second hour of the subjects' dark period and were recorded with a video camera positioned in front of the test cage. Anosmic grouped mice were employed as "standard" 
opponents because they elicit attack but never initiate such behavior [Parmigiani and Brain, 1983]. On some rare occasions, anosmic animals show aggressive behaviors, presumably due to a failure in the anosmic procedure; in these cases, the tests are interrupted and suppressed in posterior analyses.

Behavioral analysis. The behavior of experimental animals was assessed using an ethological technique based on a computerized observational procedure [Brain et al., 1989]. The behaviors are classified into the following 11 broad categories, which include a variety of different behavioral postures and elements: (1) body care (abbreviated groom, self-groom, wash, shake, scratch); (2) digging (dig, kick dig, push dig); (3) nonsocial exploration (explore, rear, supported rear, scan); (4) exploration from a distance (approach, attend, circle, head orient, stretched attention); (5) social investigation (crawl over, crawl under, follow, groom, head groom, investigate, nose sniff, sniff, push past, walk around); (6) threat (aggressive groom, sideways offensive, upright offensive, tail rattle); (7) attack (charge, lunge, attack, chase); (8) avoidance/flee (evade, flinch, retreat, ricochet, wheel, startle, jump, leave, wall clutch); (9) defensive/submissive (upright defensive, upright submissive, sideways defensive); (10) sexual behavior (attempted mount, mount); and (11) immobility (squat, cringe). A detailed description of all elements can be found in Brain et al. [1989] and Martínez et al. [1986]. The analysis of the videotapes only included the behavior of the experimental and control animals. This analysis was performed by a trained observer who was masked to the experimental group to which each animal belonged. The computer program gives information about total duration (accumulated time spent in each category). No sexual behavior was recorded, so this category does not appear in the results.

\section{Statistical Analysis}

Kruskal-Wallis tests were carried out to assess the variance in total duration in the behavioral categories. The comparisons between groups were performed using the Mann-Whitney U-test. The analyses were performed using nonparametric statistics because the criteria for parametric statistics (ANOVA) were not met by the data.

\section{RESULTS \\ Experiment 1}

Animals treated with the highest dose of lorazepam $(0.6 \mathrm{mg} / \mathrm{kg})$ were the only ones that showed a diminution in the total duration of threat $(P<.01)$ and social investigation $(P<.05)$. Only animals injected with the lowest doses of lorazepam $(0.05$ and $0.1 \mathrm{mg} / \mathrm{kg})$ spent significantly more time exhibiting body care than their controls $(P<.01$ and .05 , respectively). Apart from the lowest dose $(0.05 \mathrm{mg} / \mathrm{kg})$, treated animals spent less time exploring the environment (nonsocial exploration category) compared with the control group $(0.1,0.2$, and $0.6 \mathrm{mg} / \mathrm{kg} ; P<.01)$. The time in which they were immobilized or exploring the opponent from a distance was significantly high in all treated animals, and their statistical probability in both categories is as follows: $0.05 \mathrm{mg} / \mathrm{kg}$ of lorazepam $(P<.02) ; 0.1 \mathrm{mg} / \mathrm{kg}(P<.02) ; 0.2 \mathrm{mg} / \mathrm{kg}(P<.01$ in immobility and $P$ $<.02$ in exploration from a distance); and $0.6 \mathrm{mg} / \mathrm{kg}(P<.01)$ (see Table I).

\section{Experiment 2}

Nonstatistically significant differences were found between the experimental group (treated with Ro 15-1788 and saline solution) and their controls in all of the behavioral categories exhibited (see Table II). None of the animals of either group displayed the defense category. 
TABLE I. Median (Range) of Total Duration (in Seconds) of Behavioral Categories Displayed by Lorazepam-Treated Animals and Controls

\begin{tabular}{|c|c|c|c|c|c|}
\hline & \multirow[b]{2}{*}{ Vehicle } & \multicolumn{4}{|c|}{ Lorazepam, mg/kg } \\
\hline & & 0.05 & 0.1 & 0.2 & 0.6 \\
\hline Body care & $\begin{array}{c}7.71 \\
(1.05-48.37)\end{array}$ & $\begin{array}{c}24.74 * * * \\
(8.47-50.8)\end{array}$ & $\begin{array}{c}24.64 * \\
(7.86-72.1)\end{array}$ & $\begin{array}{c}15.39 \\
(0-54.8)\end{array}$ & $\begin{array}{c}3.8 \\
(0-63)\end{array}$ \\
\hline Digging & $\begin{array}{c}10.62 \\
(0-20.2)\end{array}$ & $\begin{array}{c}17.53 \\
(0-3.65)\end{array}$ & $\begin{array}{c}35.18 \\
(0-27.88)\end{array}$ & $\begin{array}{c}14.76 \\
(0-11.94)\end{array}$ & $\begin{array}{c}0.65 \\
(0-50.2)\end{array}$ \\
\hline $\begin{array}{l}\text { Nonsocial } \\
\quad \text { exploration }\end{array}$ & $\begin{array}{c}356.01 \\
(285.02-408.66)\end{array}$ & $\begin{array}{c}336.76 \\
(259.63-376.07)\end{array}$ & $\begin{array}{c}293.33 * * * \\
(224.7-375.82)\end{array}$ & $\begin{array}{c}291.81 * * * \\
(200.88-390.72)\end{array}$ & $\begin{array}{c}217 * * * \\
(30.9-351.3)\end{array}$ \\
\hline $\begin{array}{l}\text { Exploration } \\
\text { from a distance }\end{array}$ & $\begin{array}{c}1.74 \\
(0-5.6)\end{array}$ & $\begin{array}{c}5.1^{* *} \\
(0-19.04)\end{array}$ & $\begin{array}{c}4.74 * * \\
(0-14.89)\end{array}$ & $\begin{array}{c}4.38 * * \\
(0-23.66)\end{array}$ & $\begin{array}{c}7.3 * * * \\
(0-16.6)\end{array}$ \\
\hline Social investigation & $\begin{array}{c}40.19 \\
(3.01-207.51)\end{array}$ & $\begin{array}{c}51.03 \\
(10.45-141.15)\end{array}$ & $\begin{array}{c}33.86 \\
(0-188.36)\end{array}$ & $\begin{array}{c}51.55 \\
(2.23-116)\end{array}$ & $\begin{array}{c}16.1 * \\
(0-107.2)\end{array}$ \\
\hline Threat & $\begin{array}{c}55.19 \\
(28.65-198.98)\end{array}$ & $\begin{array}{c}42.05 \\
(20.23-117.34)\end{array}$ & $\begin{array}{c}61.18 \\
(5.32-242.85)\end{array}$ & $\begin{array}{c}72.26 \\
(0-163.19)\end{array}$ & $\begin{array}{l}14.1 * * * \\
(0-93.2)\end{array}$ \\
\hline Attack & $\begin{array}{c}67.84 \\
(3.39-149.27)\end{array}$ & $\begin{array}{c}80.41 \\
(49.59-143.98)\end{array}$ & $\begin{array}{c}97.14 \\
(0-266.92)\end{array}$ & $\begin{array}{c}124.74 \\
(0-267.87)\end{array}$ & $\begin{array}{c}53.25 \\
(0-224.2)\end{array}$ \\
\hline Avoidance/flee & $\begin{array}{c}0 \\
(0-13.49)\end{array}$ & 0 & $\begin{array}{c}0 \\
(0-1.65)\end{array}$ & $\begin{array}{c}0 \\
(0-5.2)\end{array}$ & $\begin{array}{c}0 \\
(0-16.2)\end{array}$ \\
\hline Defensive/submissive & 0 & 0 & 0 & $\begin{array}{c}0 \\
(0-2.94)\end{array}$ & $\begin{array}{c}0 \\
(0-16.7)\end{array}$ \\
\hline Immobility & $\begin{array}{c}0.58 \\
(0.03-2.45)\end{array}$ & $\begin{array}{c}1.5^{* *} \\
(0.38-2.94)\end{array}$ & $\begin{array}{c}1.3^{* *} \\
(0.27-11.46)\end{array}$ & $\begin{array}{c}4.31 * * * \\
(0.47-313.69)\end{array}$ & $\begin{array}{l}250.35 * * * \\
(0.9-569.1)\end{array}$ \\
\hline
\end{tabular}

$* P<.05$.

$* * P<.02$.

$* * * P<.01$.

\section{Experiment 3}

Those treated with lorazepam $(0.6 \mathrm{mg} / \mathrm{kg})$ and saline solution spent less time digging $(P<.001)$, threatening $(P<.001)$, and attacking $(P<.05)$ and more time avoiding the opponent $(P<.01)$ or being immobile $(P<.001)$ than the controls.

Those that received lorazepam $(0.6 \mathrm{mg} / \mathrm{kg})$ and Ro $15-1788$ showed higher total duration in the immobility category than the controls $(P<.05)$.

Comparisons between the group injected with lorazepam $(0.6 \mathrm{mg} / \mathrm{kg})$ plus saline solution and that injected with lorazepam $(0.6 \mathrm{mg} / \mathrm{kg})$ plus Ro $15-1788$ showed statistical differences in the following categories: threat, attack, avoidance, and immobility. Animals treated with lorazepam

TABLE II. Median (Range) of Total Duration (in Seconds) of Behavioral Categories Displayed by Animals That Received Saline Solution + Saline Solution or Saline Solution + Ro 15-1788 (1mg/kg)

\begin{tabular}{lcc}
\hline & Saline solution + saline solution & Saline solution + Ro-15-1788 \\
\hline Body care & $18.2(10.8-67.6)$ & $30.65(0-68.5)$ \\
Digging & $19.45(0-79.6)$ & $19.95(0-79.2)$ \\
Nonsocial exploration & $334.15(245.9-428.9)$ & $348.7(154.6-439.9)$ \\
Exploration from a distance & $0.9(0-1.3)$ & $4.1(0-11)$ \\
Social investigation & $48.1(5.8-128.8)$ & $52.45(13.9-279.4)$ \\
Threat & $60.55(0-194.9)$ & $42.65(0-120.8)$ \\
Attack & $85.85(0-194.5)$ & $50.7(0-73.2)$ \\
Avoidance/flee & $0(0-0.9)$ & $0(0-6.8)$ \\
Defensive/submissive & 0 & 0 \\
Immobility & $0.6(0.2-4.9)$ & $0.65(0.3-168.8)$ \\
\hline
\end{tabular}


and saline solution showed less total duration in threat and attack $(P<.05)$ and more in avoidance $(P<.01)$, and immobility $(P<.05)$ than those that received lorazepam and Ro 15-1788 (see Table III).

\section{DISCUSSION}

In the first experiment, the inhibition of threat could be explained in terms of general inhibition of locomotor activity as it is caused only by the highest dose of lorazepam. In addition, decreases in nonsocial exploration with all doses except the smallest one and decreases in social investigation, which were only found in those animals treated with $0.6 \mathrm{mg} / \mathrm{kg}$ of lorazepam, could also be related to benzodiazepines' sedative effects. However, the effect of lorazepam on social isolation could also be affected by the social isolation. In fact, Wongwidtdecha and Marsden [1996] found that $2.5 \mathrm{mg} / \mathrm{kg}$ of diazepam increased passive interactions in socially reared rats and decreased active interaction in isolation-reared rats, and Kumar et al. [1999] found increases in social investigation in rhesus monkeys living in social colonies, administrating 0.5 to $1 \mathrm{mg} / \mathrm{kg}$ of lorazepam together with decreases in aggression. The long duration of exploration from a distance shows, first, that this behavior is not affected by benzodiazepine sedation and, second,

TABLE III. Median (Range) of Total Duration (in Seconds) of Behavioural Categories Displayed by Animals That Received Saline Solution + Saline Solution, Lorazepam $(0.6 \mathrm{mg} / \mathrm{kg})+$ Saline Solution, or Lorazepam $(0.6 \mathrm{mg} / \mathrm{kg})+$ Ro $15-1788(1 \mathrm{mg} / \mathrm{kg})^{\mathrm{a}}$

\begin{tabular}{lccc}
\hline & $\begin{array}{c}\text { Saline solution } \\
\text { saline solution }\end{array}$ & $\begin{array}{c}\text { Lorazepam }+ \\
\text { saline solution }\end{array}$ & $\begin{array}{c}\text { Lorazepam + } \\
\text { Ro 15-1788 }\end{array}$ \\
\hline Body care & 28.65 & 19.25 & 17.5 \\
Digging & $(3.3-58.7)$ & $(0-57.9)$ & $(0-46.7)$ \\
Nonsocial exploration & 23.7 & $* * * 3$ & 8.2 \\
& $(0-71.5)$ & $(0-21.4)$ & $(0-239.9)$ \\
Exploration from a distance & 297.6 & 224.85 & 252.7 \\
& $(232.1-415)$ & $(42-385)$ & $(6.8-358.1)$ \\
Social investigation & 3.15 & 2.25 & 7.5 \\
& $(0-21.3)$ & $(0-78)$ & $(0-27.9)$ \\
Threat & 22.6 & 15.5 & 40.9 \\
& $(1.7-106.3)$ & $(0-53.5)$ & $(0-201)$ \\
Attack & 65.65 & $(0-87.7)$ & 60.4 \\
& $(29.7-151)$ & $* 67.65^{+}$ & $(0-194.8)$ \\
Avoidance/flee & 130.6 & $(0-195.3)$ & 115.8 \\
& $(56.8-240.7)$ & $* * 3.3^{++}$ & $(0-387.8)$ \\
Defensive/submissive & 0 & $(0-33.3)$ & 0 \\
Immobility & - & 0 & - \\
& 0 & $(0-90)$ & 0 \\
& - & $* * * 161.3^{+}$ & $(0-0.4)$ \\
& 0.4 & $(0-433.9)$ & $(0-202)$ \\
\hline
\end{tabular}

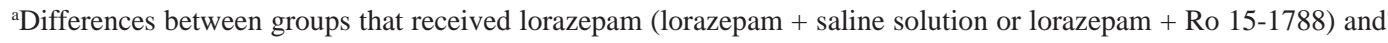
control group:

$* P<.05$.

$* * P<.01$.

$* * * P<.001$.

Differences between lorazepam + saline solution and lorazepam + Ro 15-1788 groups:

${ }^{+} P<.05$.

${ }^{++} P<.01$. 
that it could be increased to compensate for the decreases found in nonsocial exploration and social investigation. The increment of total duration in body care with low doses of lorazepam $(0.05$ and $0.1 \mathrm{mg} / \mathrm{kg}$ ) could be related to the rare disinhibitory action of benzodiazepines and, in some aspects, to the interaction between GABAergic and dopaminergic neurotransmission.

Interestingly, behavioral effects of $0.6 \mathrm{mg} / \mathrm{kg}$ of lorazepam were slightly different in the third experiment. Exploratory behaviors were unaffected by lorazepam, whereas there was an increment of defensive behaviors and an inhibition of threat and attack due to lorazepam treatment. The action on offensive behaviors, such as occurred in the first experiment, could be explained by lorazepam-induced sedation, as was shown by the dramatic increase in immobility, which is not completely antagonized by flumazenil. This fact could support the idea that the sedative effects of benzodiazepines could be modulated not only by benzodiazepine receptor ligands. As observed, controls of both experiments showed differences in exploratory and offensive behaviors, probably due to the stressing effect of handling and injections because there were two injections within a short interval. This stressing effect could also explain the increases in avoidance and nonsocial exploration. These previously mentioned differences could be responsible for the varying action of lorazepam administered at the same dose and with the same method. Weerts et al. [1992] found that mice selectively bred depending on aggression levels criteria had a different response to benzodiazepine treatment, which means a different response to the GABAdependent chloride uptake. High doses of chlordiazepoxide (17 and $30 \mathrm{mg} / \mathrm{kg}$ ) in aggressive mice decreased motor behavior and in low-aggressive mice increased social behavior and reduced aggression. Furthermore, the GABA-dependent chloride uptake was affected differently, augmented in low-aggressive mice and decreased in high-aggressive mice. Other studies have showed that the proaggressive effects of benzodiazepines have been observed in animals with previous fighting experiences [Ferrari et al., 1997; Palanza et al., 1996; Parmigiani et al., 1998]. In the present study, controls in the third experiment spent more time in social investigation and less in attack categories than controls of the first experiment.

Our most remarkable findings are that flumazenil was successful in completely antagonizing the behavior modulated by lorazepam (immobility, attack, threat, and digging) at $0.6 \mathrm{mg} / \mathrm{kg}$ dose and that some (potentially emotion-related) behaviors (social investigation, threat, and attack) may be disinhibited at low doses of lorazepam.

\section{ACKNOWLEDGMENTS}

We thank Ms. Miriam Phillips for the revision of the English text.

\section{REFERENCES}

Bieniek SA, Ownby RL, Penalver A, Dominguez RA. 1998. A double-blind study of lorazepam versus the combination of haloperidol and lorazepam in managing agitation. Pharmacotherapy 18:57-62.

Bonetti EP, Pieri L, Cumin R, Schaffner R, Pieri M, Gamzu ER, Muller RK, Haefely W. 1982. Benzodiazepine antagonist Ro 15-1788: neurological and behavioral effects. Psychopharmacology (Berl) 78:8-18.

Borgesova M, Kadledecova O, Krsiak M. 1971. Behaviour of untreated mice to alcohol or chlordiazepoxidetreated partners. Activitas Nervosa Superior (Praha) 13:206-207.
Brain PF, McAllister KH, Walmsley S. 1989. Drug effect on social behavior: methods in ethopharmacology. In: Boulten AA, Baker GB, Greenshaw AJ, editors. Neuromethods: psychopharmacology. Totowa, NJ: Humana Press. p 687-739.

Buckley PF. 1999. The role of typical and atypical antipsychotic medications in the management of agitation and aggression. J Clin Psychiatry 60:52-60.

Christmas AJ, Maxwell DR. 1970. A comparison of the effects of some benzodiazepines and other drugs on aggressive and exploratory behaviour in mice and rats. Neuropharmacology 9:17-29. 
Cilia J, Piper DC. 1997. Marmoset conspecifics confrontation: an ethologically-based model of anxiety. Pharmacol Biochem Behav 58:85-91.

Corda MG, Costa E, Guidotti A. 1982. Specific proconvulsant action of an imidazobenzodiazepine (Ro 15-1788) on isoniazid convulsions. Neuropharmacology 21:91-94.

Cutler MG, Rodgers RJ, Jackson JE. 1997. Behavioural effects in mice of subchronic chlordiazepoxide, maprotiline, and fluvoxamine, I: social interactions. Pharmacol Biochem Behav 57:119-125.

Da Vanzo JP, Daugherty M, Ruckart R, Kang L. 1966. Pharmacological and biochemical studies in isolation-induced fighting mice. Psychopharmacologia 9:210-219.

Delini-Stula A, Vassout A. 1979. Differential effects of psychoactive drugs on aggressive responders in mice and rats. In: Sandler M, editor. Psychopharmacology of aggression. New York, NY: Raven Press. p 41-60.

Dorevitch A, Katz N, Zemisnlany Z, Aizenberg D, Weizman A. 1999. Intramuscular flunitrazepam versus intramuscular haloperidol in the emergency treatment of aggressive psychotic behavior. Am J Psychiatry $156: 142-144$.

Feldman MD. 1986. Paradoxical effects of benzodiazepines. N C Med J 47:311-312.

Ferrari PF, Parmigiani S, Rodgers RJ, Palanza P. 1997. Differential effects of chlordiazepoxide on aggressive behavior in male mice: the influence of social factors. Psychopharmacology 134:258-265.

File SE. 1982. Recovery from lorazepam tolerance and the effects of benzodiazepine antagonist (Ro 15-1788) on the development of tolerance. Psychopharmacology (Berl) 77:284-288.

Krsiak M. 1975. Timid singly-housed mice: their value in prediction of psychotropic activity of drugs. Br J Pharmacol 55:141-150.

Krsiak M. 1979. Effects of drugs on behaviour of aggressive mice. Br J Pharmacol 65:525-533.

Krsiak M, Sulcova A. 1990. Differential effects of six structurally related benzodiazepines on some ethological measures of timidity, aggression and locomotion in mice. Psychopharmacology 101:396-402.

Krsiak M, Sulcova A, Tomasikova Z, Dlohozkova N, Kosar E, Masek K. 1981. Drug effects on attack defense and escape in mice. Pharmacol Biochem Behav 14:47-52.

Kumar R, Palit G, Singh JR, Dhawan BN. 1999. Comparative behavioural effects of benzodiazepine and non-benzodiazepine anxiolytics in rhesus monkeys. Pharmacol Res 39:437-444.

Lenox RH, Newhouse PA, Creelman WL, Whitaker TM 1992. Adjunctive treatment of manic agitation with lorazepam versus haloperidol: a double-blind study. J Clin Psychiatry 53:47-52.

Mandel P, Haug M, Puglisi S, Kempf E, Mack G. 1981.
Involvement of the GABAergic system in aggressive behaviour. In: Brain PF, Benton D, editors. Biology of aggression. Alphen aan den Rijn, the Netherlands: Sitjhoff and Noordhoff International Publishers BM. p 169-174.

Martínez M, Castaño D, Simón VM, Brain PF. 1986. An ethopharmacological assessment of the influences of ciproterone acetate on social interactions in male mice. IRCS Med Sci Res 14:44-45.

Miachon S, Cespuglio R. 1997. Prevention of ACTH- and adrenalectomy-induced muricidal behavior: by benzodiazepinic ligands. Peptides 18:185-189.

Miczek KA, O'Donnell JM. 1980. Alcohol and chlordiazepoxide increase suppressed aggression in mice. Psychopharmacology 69:39-44.

Miczek KA, Weerts E, Haney M, Tidey J. 1994. Neurobiological mechanism controlling aggression: preclinical developments for pharmacotherapeutic interventions. Neurosci Biobehav Rev 18:97-110.

Mos J, Olivier B. 1989. Quantitative and comparative analyses of pro-aggressive actions of benzodiazepines in maternal aggression of rats. Psychopharmacology (Berl) 97:152-153.

Nutt DJ, Cowen PH, Little HJ. 1982. Unusual interactions of benzodiazepine receptor antagonists. Nature 295:436-438.

Pabis DJ, Stanislav SW. 1996. Pharmacotherapy of aggressive behavior. Ann Pharmacother 30:278-287.

Palanza P, Rodgers RJ, Ferrari PF, Parmigiani S. 1996. Effects of chlordiazepoxide on maternal aggression in mice depend on experience of resident and sex of intruder. Pharmacol Biochem Behav 54:175-182.

Parmigiani S, Brain PF. 1983. Effects of residence, aggressive experience and intruder familiarity on attack shown by male mice. Behav Proc 8:45-57.

Parmigiani S, Ferrari PF, Palanza P. 1998. An evolutionary approach to behavioral pharmacology: using drugs to understand proximate and ultimate mechanisms of different forms of aggression in mice. Neurosci Biobehav Rev 23:143-153.

Poole TB. 1973. Some studies on the influence of chlordiazepoxide on the social interaction of golden hamsters (Mesocricetus auratus). Br J Pharmacol 48: 538-545.

Poshivalov VP, Nieminen SA, Airaksinen MM. 1987. Ethopharmacological studies of the effects of bcarbolines and benzodizepines on murine aggression. Aggr Behav 13:141-147.

Rodgers RJ, Randall JI. 1987. Are the analgesic effects of social defeat mediated by benzodiazepine receptors? Physiol Behav 41:279-289.

Rodgers RJ, Randall JI. 1988. Potent inhibition of nonopioid defeat analgesia in male mice by benzodiazepine antagonist Ro 15-3505. Physiol Behav 42: 461-464.

Rodgers RJ, Waters AJ. 1984. Effects of the benzodiaz- 
epine antagonist Ro 15-1788 on social and agonistic behaviour in male albino mice. Physiol Behav 33: 401-409.

Rodgers RJ, Waters AJ, Rosenfield S. 1983. Evidence for intrinsic behavioural activity of the benzodiazepine antagonist, Ro 15-1788, in male mice. Pharmacol Biochem Behav 19:895-898.

Salzman C, Solomon D, Miyawaki E, Glassman R, Rood L, Flowers E, Thayer S. 1991. Parenteral lorazepam versus parenteral haloperidol for the control of psychotic disruptive behavior. J Clin Psychiatry 52:177-180.

Scriabine A, Blake M. 1962. Evaluation of centrally acting drugs in mice with fighting behavior induced by isolation. Psychopharmacologia 3:224-226.

Skolnick P, Reed GF, Paul SM. 1985. Benzodiazepinereceptor mediated inhibition of isolation-induced aggression in mice. Pharmacol Biochem Behav 23: 17-20.

Sofia RD. 1969. Effects of centrally active drugs on four models of experimentally-induced aggression in rodents. Life Sci 8:705-716.

Sulcova A, Krsiak M. 1989. Differences among nine 1,4benzodiazepines: an ethopharmacological evaluation in mice. Psychopharmacology 97:157-159.

Vale AL, Montgomery AM. 1997. Social interaction: re- sponses to chlordiazepoxide and the loss of isolationreared effects with paired-housing. Psychopharmacology (Berl) 133:127-132.

Valzelli L, Bernasconi S. 1976. Psychoactive drug effect on behavioural changes induced by prolonged socio-environmental deprivation in rats. Psychol Med 6:271-276.

Valzelli L, Giacalone E, Garattini S. 1967. Pharmacological control of aggressive behavior in mice. Eur $\mathbf{J}$ Pharmacol 2:144-146.

Weerts EM, Miczek KA. 1996. Primate vocalizations during social separation and aggression: effects of alcohol and benzodiazepines. Psychopharmacology (Berl) 127:255-264.

Weerts EM, Miller LG, Hood KE, Miczek KA. 1992. Increased GABAA-dependent chloride uptake in mice selectively bred for low aggressive behavior. Psychopharmacology (Berl) 108:196-204.

Weisman AM, Berman ME, Taylor SP. 1998. Effects of chlorazepate, diazepam, and oxazepam on a laboratory measurement of aggression in men. Int Clin Psychopharmacol 13:183-188.

Wongwidtdecha N, Marsden CA. 1996. Social isolation increases aggressive behaviour and alters the effects of diazepam in the rat social interaction test. Behav Brain Res 75:27-32. 